\title{
Computer Competency Level of Elementary Teachers of Southern Tabuk District-1
}

\author{
Paulino P. Reyes II* \\ College of Education, Kalinga State University, Bulanao, Tabuk City, Kalinga, Philippines; averille04@gmail.com
}

\begin{abstract}
Objectives: The study determined the computer competency level of the elementary teachers of Southern Tabuk District-1, extent of use of computer in teaching the different learning areas and identify the problems encountered by teachers in using computer programs. Methods/statistical analysis: The research applied the descriptive design method in this study. The frequency count percentage and the weighted mean were employed to treat the data on the profile variables of the respondents. The analysis of variance (ANOVA) was used to determine the significant differences in the perceptions of the respondents. It described the functional computer competency of elementary teachers along moderator variables: age, gender, and years of service in teaching. Findings: In the conducted study of the computer competency level of elementary teachers in Southern Tabuk District-1, the perceptions of the respondents on the use of computer along Microsoft Applications is not significant. Therefore, for trainings, technical support, and time to learn these skills were needed by the respondents. In the extent to use computer in different subject areas, age and gender show no significant difference, but years of service in teaching has a significant difference on the use of computer. This only implies that younger teachers in the service are more exposed and competent in the use of computer compare to those teachers who 21 years above in the teaching. Problems were also identified in the study; respondents specify each problem from most to least. Inadequate training is identified first, followed by insufficient time to learn computer, third is too much work at home, fourth is dependence on colleagues, fifth is negative attitude towards computer, sixth is slow internet accessibility, and lastly has no computer to use. Application/improvement: This study could be a springboard for the district to prepare a program to enhance the skills of the teachers on the use of computer and to level up their competencies into this endeavour.
\end{abstract}

Keywords: Competency, Competency Level, Computer, Elementary Teachers, Southern Tabuk, District.

\section{Introduction}

"Change is inevitable". In our ever-changing society, it is indeed that technology is rapidly evolving. Modern technology has given us opportunity to make our work faster and understanding how to operate these technologies become more and more essential. Today, most of the high demand jobs require abilities on how to operate computer, thus, one must be competent to meet the demands of time. Our Philippine educational system is undergoing a massive change with the advent of technology in the $\mathrm{K}-12$ curriculum. The use of Information and Communication Technology (ICT) such as Internet applications and various computer attachments and software programs have caused many changes in society. As part of the change, the role of schools and education will also be different both in the education system and in society. 1 With the rapid rise of these improved and sophisticated technologies, the basic knowledge is often termed as "Computer Awareness". However, teachers must not only aware but also computer competent in order to be equipped with the 21st century skills. As to Far and in Ref., $\underline{2}$ they define computer competency as an individual's ability to effectively use computer technology and adapt his or her knowledge and skills to a variety of particular uses and settings. Specifically, computer competency refers to an individual's ability to operate a computer system, have a basic understanding of the

${ }^{*}$ Author for correspondence 
operating system, use computer application software to perform personal or job-related tasks, use Web browsers and search engines on the Internet to retrieve and store needed information, and communicates with others. The term "computer competency" is most often used interchangeably with and treated as synonymous to terms such as "computer literacy" and "computer skills," which refer to an individual's ability to effectively use available computer information systems available and adapt his or her skill set to a variety of settings. $\underline{\underline{3}}$

\section{Conceptual Framework}

Computer technology has opened wide opportunities for teachers to integrate computers in teaching-learning process. Computers greatly facilitate teaching-learning process for various curricular subjects especially language, mathematics, and science. Computer technology is also being increasingly applied in non-instructional (record keeping, grade averaging, communication, etc.) and pre-instructional (developing instructional materials, researching instructional content, etc.) uses. Computer competence is being able to handle a wide range of varying computer applications for various purposes. Teachers are then and should be equipped with skill in handling these Microsoft applications that he/ can use in the teachinglearning process.

The use of computer in education is a unique opportunity for teacher as computer is not only for the benefits of the learners but also in teacher's professional growth. These advantages or benefits include the provision of a qualitative access to education. ${ }^{4}$ It also promotes valid sustainable strategy. $\underline{5}$ Furthermore, it promotes changes in attitudes, behaviour and values, as well as in the cognitive and perceptive processes. So teachers must be computer competent to achieve these benefits.

In Ref., $\underline{6}$ Authors investigated Turkey primary school science' use of computer applications. Results demonstrated that improving the computer literacy of science teachers seems to increase science teachers' computer use and consequently increase their integration of computer applications as an instructional tool. Internet, email, and educational software CDs found to have a high percentage in teachers' use of computer applications in the classroom.

In Ref. $\underline{7}$ of Cyprus, explored transforming a teacher education course through technology effects on preservice teachers' technology competency. The result indicated that the risk of preparing prescience teachers to become technology competent was difficult and requires many efforts for providing them with technology in their classes. In a similar research by Ref., $\underline{8}$ the effects of a long-duration, professional developments academy on technology skills, computer integration beliefs, and practices were studied and the results reported significant gains in participants' self-assessed technology skills and computer self-efficacy, with little or no change to selfassessed technology integration beliefs and practices.

Trainings are said to have great impact on teachers' computer competency, but lack of it causes teachers to encounter problems in dealing with computers. In the study of the ICT Competency level of Teacher Education in Central Visayas found out that teachers are good in word processing, spreadsheet, presentation, videos and digital materials, downloading and uploading content from the web. But in Negros Occidental despite of the awareness of the teachers, few have experience in classroom integration. One of the problems of teachers in the integration as said by many researchers and studies is lack of computer training among the teachers. Results of survey by Ertmer et al., 9 Australian teachers' lack of knowledge/skills in computer was one of the major reasons the unsuccessful implementation of computers in school.

Relevant to result,,$\underline{10}$ the study emphasises that there is a need for computer trainings for teachers in the sense that the computer failed in classroom instruction because the teachers lack the skills to implement instructional competency. Training is found to increase their use of technology in the classroom, and to use it more creatively. $\underline{11}$

As supported by the study of Hermans et al. $\underline{12}$ in Eastern Tabuk District among 148 respondents reveal that those who attended formal training have a positive impact in integrating ICT in their classroom.

In Ref. $\frac{13}{}$, in their study among the 62 public elementary teachers of San Jose Elementary school, Division of Tacloban city, concluded that teachers have basic computer competency and it needs to be proficient in knowing where and when to use technology for teaching and other related tasks. It is then recommended that teachers undergo training that will help further enhance their computer skills and knowledge. Teachers' professional development is a key factor to successful integration of computers in classroom teaching. 
In Ref. $\underline{14}$ that teachers and school administrators much ensure that computers in the access centers or laboratories are utilised for beneficial activities and not merely for recreational activities such as playing games or online chatting. Applications such as spreadsheet, database, word processing, and introduction should be utilised for educational purposes as well searching for useful info via web browsing. As to Hus, $\frac{15}{}$ using computers more frequently and developing a variety of computer-related skills and techniques increases one's knowledge of the computer as a whole.

Age and gender have been the factors that affect a teacher level of competency in computer. As to age, in the survey conducted by Johnson et al., $\underline{16}$ on teachers of Uttarakhand, observed that teachers who are above 40 years of age and teachers with 20 years of experience and above showed a favorable opinion but used less in the classroom. Also, in the study of, found out than in the use of computers, teachers in the age group 30-39 have used computer in the class more than the teachers of other groups (40-49 and $50+$ ). This could be because those teachers were more exposed to the computers than the senior teachers. As to gender, $\underline{17}$ study reported that there is no difference between the perceptions of urban and rural teachers and male and female teachers. While some studies found no gender deference in attitude towards computers, $\underline{18-\underline{20}}$ other studies indicate that gender plays a role.

Given the importance of teachers' computer competencies to the successful infusion of computers into curriculum. It ignites the interest of the researcher to find the level of computer competency of elementary teachers of Southern Tabuk District-1 along with the moderator: age, gender, and years of teaching. Paradigm of the study are shown in Figure 1.

\section{Results and Discussion}

This chapter presents the analysed and interpreted responses on the computer competency level of elementary teachers of Southern Tabuk District-1, Division of Tabuk City for the School Year 2018-2019.

It specifically presents the discussion on the computer competency level by which the teacher used computer applications such as Microsoft Word, Microsoft Excel, Microsoft Publisher, Microsoft PowerPoint, and Web browser. Also, the extent of use of computer in teaching the different subject areas and problems encountered on the use of it.

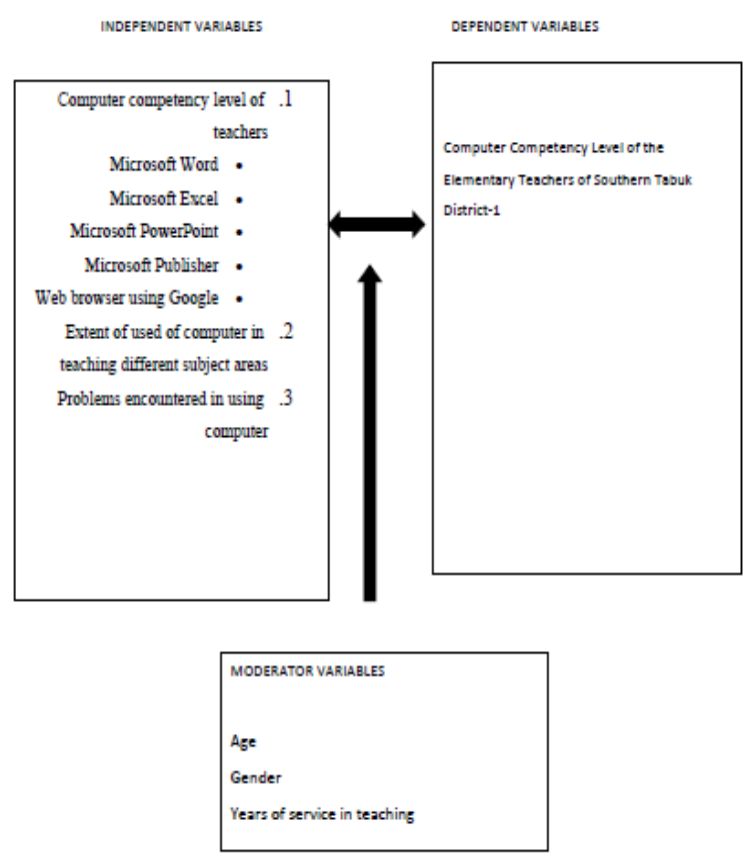

Figure 1. Paradigm of the study.

Table 1 presents the computer competency level of elementary teachers of Southern Tabuk District-1 along Microsoft Word.

The table shows a total average weighted mean of 2.91 which is described as Much Competent. The elementary teachers of Southern Tabuk District-1 were described to be much competent in Microsoft Word. The highest mean was obtained along printing documents and saving documents, teachers at present just download documents in websites, saving it with few edit then print which this gives an easy option for teachers rather than preparing and encoding. In encoding documents though described to be much competent obtained low, as teachers were not encode their daily lesson log but rely in ready-made downloaded lesson plans. They edit some instructions to fit in the skills of their learners.

The respondents were moderately competent along inserting pictures, lay outing documents, scan documents, working with tables, and making illustrations with graphical form. The lowest mean was obtained along scan documents for teachers seldom scan their documents. The said activity is only done when it is needed.

Word processors are of importance for the occupations where writing is necessary. It is revealed that the respondents are much competent in using the Microsoft word. This study is supported by the study of Padmavathi 21 
Table 1. Computer competency level of elementary teachers of Southern Tabuk District-1 along Microsoft Word $(\mathrm{N}=$ $55)$

\begin{tabular}{|l|l|l|l|l|l|}
\hline Microsoft Word & MC-3 & MOC-2 & LC-1 & Weighted mean & Description \\
\hline 1. Encoding documents & $28(84)$ & $21(42)$ & $6(6)$ & 2.4 & MC \\
\hline 2. Inserting pictures & $27(81)$ & $15(30)$ & $13(13)$ & 2.25 & MOC \\
\hline 3. Lay outing documents & $16(48)$ & $23(46)$ & $15(15)$ & 1.98 & MOC \\
\hline 4. Scan documents & $15(45)$ & $23(46)$ & $10(10)$ & 1.83 & MOC \\
\hline 5. Working with tables & $24(72)$ & $19(38)$ & $12(12)$ & 2.21 & MOC \\
\hline 6. Making illustrations with graphical form & $16(48)$ & $26(52)$ & $13(13)$ & 2.05 & MOC \\
\hline 7. Saving documents & $37(111)$ & $13(26)$ & $5(5)$ & 2.58 & MC \\
\hline 8. Printing documents & $37(111)$ & $13(26)$ & $5(5)$ & 2.58 & MC \\
\hline 9. Creating folders for documents & $33(99)$ & $17(34)$ & $5(5)$ & 2.50 & MC \\
\hline Total average weighted mean & & & & 2.91 & MC \\
\hline
\end{tabular}

that primary teachers in Selcuk University, Turkey almost proficient in the use of word processor.

Table 2 presents the computer competency level of elementary teachers of Southern Tabuk District-1 along Microsoft Excel.

It is shown in the table that the total weighted mean is 2.02 which is described as Moderately Competent. This means that the computer competency level of elementary teachers of Southern Tabuk District-1 were moderately competent in Microsoft Excel. The highest mean was obtained along encoding documents in a worksheet. When all the School forms (SF 1-10) and the Learners Information System (LIS), were encoded in Microsoft Excel, teachers must encode necessary data to be submitted to the Division office using Excel. This collaborates with the result that teachers can able to encode data in a worksheet but not yet proficient. It was also more convenient to work, especially when dealing with many working tables.

The lowest mean described to be less competent was obtained along filtering and sorting data. To filter and sort data means to arrange it alphabetically (A-Z). Many teachers do not filter and sort their data for they already pre-planned and arranged their data before encoding. But teachers must know these to be able to check if their data were properly arranged.

Microsoft Excel was often used by teachers, but the results revealed that respondents still need formal computer trainings to be competent in using it. The use of these programs should be given priority for teachers to cope up with all the school forms. The result collaborates with the study of the elementary teachers of Eastern
Tabuk District wherein teachers who have no formal trainings were moderately competent in Microsoft Excel.

Table 3 presents the computer competency level of elementary teachers of Southern Tabuk District-1 along Microsoft PowerPoint.

Table 3 revealed that the total weighted mean is 2.14 described as Moderately Competent. This means that the computer competency level of elementary teachers in Southern Tabuk District-1 in Microsoft PowerPoint is moderately competent. They all obtained moderately competent in all variables and the highest mean was obtained along creating a slideshow, to create a slideshow means inputting data on a blank slide. The result revealed that teachers can create their own PowerPoint but not yet proficient. The lowest mean was obtained along designing a slideshow and adding background to slideshow. The fact that teachers have a basic knowledge in creating slideshows does not mean they know how to design and add background to it. To design is using and adding some effects to the slideshow to make the slideshow more interesting. Some teachers prefer simple slideshows for easy tasks and refuse to add designs. One factor is that teachers are fond of downloading ready-made PowerPoints that were already designed, and they use it directly in their teaching.

The study shows that teachers still need to enhance their skills in doing their own PowerPoint Presentation. In fact, these programs are so necessary for teachers wherein teachers can present a lesson from the beginning to the end by using such features as picture, graphic, table, sound and animation together with data show tools. Using these programs in education will have a positive impact 
Table 2. Computer competency level of elementary teachers of Southern Tabuk District-1 along Microsoft Excel $(\mathrm{N}=$ 55)

\begin{tabular}{|l|l|l|l|l|l|}
\hline Microsoft Excel & MC & MOC & LC & Weighted mean & Description \\
\hline 1. Encoding documents in a worksheets & $24(72)$ & $23(46)$ & $8(8)$ & 2.29 & MOC \\
\hline 2. Using formulas and functions & $13(39)$ & $25(50)$ & $17(17)$ & 2.25 & MOC \\
\hline 3. Inserting formulas and functions & $11(33)$ & $23(46)$ & $21(21)$ & 1.81 & MOC \\
\hline 4. Creating charts & $17(51)$ & $24(48)$ & $14(14)$ & 2.05 & MOC \\
\hline 5. Merging tables & $23(69)$ & $18(36)$ & $14(14)$ & 2.16 & MOC \\
\hline 6. Formatting a worksheet & $16(48)$ & $22(44)$ & $17(17)$ & 1.98 & MOC \\
\hline 7. Filtering \& sorting data & $14(28)$ & $23(46)$ & $17(17)$ & 1.65 & LC \\
\hline Total weighted mean & & & & 2.02 & MOC \\
\hline
\end{tabular}

Table 3. Computer competency level of elementary teachers of Southern Tabuk District-1 along Microsoft PowerPoint $(\mathrm{N}=55)$

\begin{tabular}{|l|l|l|l|l|l|}
\hline Microsoft PowerPoint & MC-3 & MOC-2 & LC-1 & Weighted mean & Description \\
\hline 1. Creating a slide show & $29(87)$ & $14(28)$ & $12(12)$ & 2.30 & MOC \\
\hline $\begin{array}{l}\text { 2. Inserting graphs and charts in a } \\
\text { slideshow }\end{array}$ & $23(69)$ & $16(32)$ & $16(16)$ & 2.12 & MOC \\
\hline $\begin{array}{l}\text { 3. Adding animations and transitions in a } \\
\text { slideshow }\end{array}$ & $21(63)$ & $19(38)$ & $15(15)$ & 2.10 & MOC \\
\hline 4. Designing a slideshows & $22(66)$ & $16(32)$ & $17(17)$ & 2.09 & MOC \\
\hline 5. Adding background in a slideshow & $22(66)$ & $16(32)$ & $17(17)$ & 2.09 & MOC \\
\hline Total weighted mean & & & & 2.14 & MOC \\
\hline
\end{tabular}

on student's attention, motivation, and attitudes by both making teaching and learning active, causing teachers to get tired less. $\underline{22}$

Table 4 presents the computer competency level of elementary teachers of Southern Tabuk District-1 along Microsoft Publisher.

Table 4 shows that the total weighted mean of 2.16 is Moderately Competent. This means that the competency level of the elementary teachers of Southern Tabuk District-1 in Microsoft publisher is Moderately Competent. The highest mean was obtained in lay outing pictures, this in collaborates with the result in Table 4 that teachers prefer to lay out pictures in Microsoft publisher than in Microsoft word. Documentations are very particular in teaching today, all school activities are required to be documented, so teachers must lay out these pictures taken. In creating certificates obtained a mean of 2.05 which is described as moderately competent. To create a certificate is also a necessary as school activities nowadays requires certificates to be awarded to pupils and teachers as well, so teachers must be competent on how to make certificates. As teachers at present can conduct in-service trainings and LAC sessions in school, he/she must provide certificates to the participants.

Table 4. Computer competency level of elementary teachers of Southern Tabuk District-1 along Microsoft Publisher $(\mathrm{N}=55)$

\begin{tabular}{|l|l|l|l|l|l|}
\hline Microsoft Publisher & MC-1 & MOC-2 & LC-1 & Weighted mean & Description \\
\hline 1. Lay outing pictures & $18(54)$ & $24(48)$ & $13(13)$ & 2.63 & MC \\
\hline 2. Creating certificates & $21(63)$ & $16(32)$ & $18(18)$ & 2.05 & MOC \\
\hline 3. Creating advertisement and calendars & $12(36)$ & $20(40)$ & $23(23)$ & 1.8 & MOC \\
\hline Total weighted mean & & & & 2.16 & MOC \\
\hline
\end{tabular}


The lowest mean was obtained by creating advertisement and calendars. Teachers are not likely to do their own school calendar; the Department of Education provides ready-made school year calendars for teachers to be guided by the different school activities. This is in collaborates with the study that teachers of Eastern Tabuk District obtained the lowest mean in creating calendars and advertisement. Though these skills are seldom practice, there is still a need to be competent.

Microsoft publisher is very convenient to use especially in picture and certificates, so teachers must be competent in using this program. There are many features that it offers especially in making invitations, flyers, posters, school papers, and certificates. In the study of Teck and Lai $\underline{23}$ that the teachers in Southern Pinukpuk District are very much benefited in the use of Microsoft publisher.

Table 5 presents the computer competency level of elementary teachers of Southern Tabuk District-1 along web browser.

As expressed in Table 6, the total weighted mean is 2.12 which is described as Moderately Competent. This means that the competency level of the elementary teachers of Southern Tabuk District-1 in web browser is moderately competent. The highest mean described to be much competent was obtained along use of Wi-Fi and using Facebook/Instagram/tweeter. Today, the widespread use of Facebook among teachers is thought to be natural simply because the access to internet is not only limited to the use of personal computers but also to mobile phones. According to the website Statista, as of per quarter of 2016, Facebook had 1.65 billion monthly active users. Teachers can use their mobile phone to search, share, download files and communicate virtually to different teachers' groups in Facebooks that offers ready-made instructional materials.

The respondents were moderately competent along Website surfing/searching, downloading documents and educational videos from websites, creating and using of email or account, and sending documents through email. The lowest mean was obtained in uploading documents or videos in websites. This remains a problem to many teachers wherein they know how to download but less in uploading. Some rely to younger colleagues or computer shop to assist them. Trainings and peer support were one of the eyed solutions to this problem.

Table 7 presents the summary of mean of the level of computer competency of the elementary teachers of Southern Tabuk District-1 along the following Microsoft applications.

Table 7 shows that the computer competency level of elementary teachers of Southern Tabuk District-1 along the Microsoft Applications is moderately competent. The highest mean was obtained by Microsoft word which is described as Much Competent, thus the respondents are much competent in the use of Microsoft word. Moderately competent were obtained along the use of Microsoft Excel, Microsoft PowerPoint, Microsoft Publisher, and Web browser.

The lowest mean was obtained by Microsoft excel with a mean of 2.02. This implies that teachers still lack knowledge in the use of excel. Thus, this should be given priority during seminars and trainings, especially that the majority of the school forms were done in Excel.

Table 8 presents the summary of ANOVA as to perceptions of the elementary teachers of Southern Tabuk District-1 level of computer competency along the following Microsoft Applications.

Table 5. Computer competency level of elementary teachers of Southern Tabuk District-1 along web browser $(\mathrm{N}=55)$

\begin{tabular}{|l|l|l|l|l|l|}
\hline Web browser & MC-3 & MOC-2 & LC-1 & Weighted mean & Description \\
\hline 1. Website surfing/searching & $28(84)$ & $14(28)$ & $12(12)$ & 2.25 & MOC \\
\hline $\begin{array}{l}\text { 2. Downloading documents and educational } \\
\text { videos from websites. }\end{array}$ & $23(69)$ & $19(38)$ & $8(8)$ & 2.09 & MOC \\
\hline 3. Uploading documents or videos in websites & $24(72)$ & $18(36)$ & $13(13)$ & 1.21 & 1C \\
\hline 4. Use of Wi-Fi or internet & $31(93)$ & $14(28)$ & $9(9)$ & 2.36 & MC \\
\hline 5. Creating and using of Email or account & $29(87)$ & $15(30)$ & $11(11)$ & 2.32 & MOC \\
\hline 6. Sending documents through email & $26(78)$ & $16(32)$ & $13(13)$ & 2.23 & MOC \\
\hline 7. Using Facebook/Instagram/tweeter & $30(90)$ & $17(34)$ & $8(8)$ & 2.4 & MC \\
\hline Total weighted mean & & & & 2.12 & MOC \\
\hline
\end{tabular}


Table 6. Frequencies of the elementary teachers of Southern Tabuk District-1 extent of use of computer in teaching the different subject areas

\begin{tabular}{|l|l|l|l|l|}
\hline Different subject areas & O & S & N & Mean \\
\hline English & $17(51)$ & $32(64)$ & $6(6)$ & 2.2 \\
\hline Mathematics & $12(36)$ & $34(68)$ & $9(9)$ & 2.05 \\
\hline Science & $17(54)$ & $33(66)$ & $5(5)$ & 2.27 \\
\hline Filipino & $16(48)$ & $32(64)$ & $7(7)$ & 2.16 \\
\hline Araling Panlipunan & $14(42)$ & $36(72)$ & $5(5)$ & 2.16 \\
\hline MAPEH & $12(36)$ & $36(72)$ & $7(7)$ & 2.09 \\
\hline $\begin{array}{l}\text { Edukasyonsa } \\
\text { Pagpapakatao/values } \\
\text { education }\end{array}$ & $12(36)$ & $37(74)$ & $6(6)$ & \\
\hline Total weighted mean & & & & 2.10 \\
\hline
\end{tabular}

Table 7. Summary of mean of the level of computer competency of elementary teachers of Southern Tabuk District-1 along the following Microsoft applications

\begin{tabular}{|l|l|l|}
\hline Microsoft applications & Mean & Description \\
\hline Microsoft Word & 2.91 & MC \\
\hline Microsoft Excel & 2.02 & MOC \\
\hline Microsoft Powerpoint & 2.14 & MOC \\
\hline Microsoft Publisher & 2.16 & MOC \\
\hline Web browser & 2.12 & MOC \\
\hline Total weighted mean & 2.27 & MOC \\
\hline
\end{tabular}

Since the computed $F$-test of 0.548 is lesser than the $F$-critical value of 2.74 , the null hypothesis which states that there are no significant differences in the perceptions of the respondents on the level of computer competency of elementary teachers along the following computer applications: Microsoft Word, Microsoft Excel, Microsoft Publisher, Microsoft PowerPoint, and Web browser is accepted. Therefore, there are no significant differences in the perceptions of the respondents on the level of computer competency of elementary teachers along the computer applications such as Microsoft Word, Microsoft Excel, Microsoft Publisher, Microsoft PowerPoint, and Web browser.

\subsection{Extent of Used of Computer in Teaching the Different Subject Areas}

Table 6 presents the frequencies of the elementary teachers of Southern Tabuk District-1 extent of use of computer in teaching different subject areas.

Table 6 revealed that the total weighted mean is 2.14 which is interpreted as sometimes used. This means that the elementary teachers of Southern Tabuk District-1 sometimes used computer in their classrooms as their aid in teaching.

\subsection{Extent of Used of Computer in Teaching the Different Subject Areas as to Moderator Variables of Age, Gender, and Years of Service in Teaching}

This section presents the findings on the respondents' frequency on the extent of use of computer as influenced by their age, gender, and years of service in teaching.

Table 9 presents the extent of use of computer in teaching the different subject areas of the elementary teachers of Southern Tabuk District-1 as to moderator of age.

Since the computed F-test of 6.346 is lesser than the $F$-critical value of 9.49 , the null hypothesis which states that there are no significant differences on the extent of use in teaching the different subject areas as to age is accepted. Thus, this implies that the computer usage does not differ as to age. Therefore, there are no significant differences on the extent of use in teaching the different subject areas as to age.

Table 9 presents that age of the respondents does not affect their use of computer. Some of the respondents were already old before they enter in their teaching

Table 8. Summary of ANOVA as to level of computer competency of elementary teachers of Southern Tabuk District-1 along the following Microsoft applications

\begin{tabular}{|l|l|l|l|l|l|l|}
\hline Source of variation & SS & df & MS & $\boldsymbol{F}$ & $\boldsymbol{P}$-value & $\boldsymbol{F}$ crit \\
\hline Between Groups & 0.196494 & 4 & 0.049124 & 0.548433 & 0.70177 & 2.742594 \\
\hline Within Groups & 2.328841 & 26 & 0.089571 & & & \\
\hline Total & 2.525335 & 30 & & & & \\
\hline
\end{tabular}

$F=0.548<F$-crit. $=2.74$, Decision: accept Ho/not significant. 
Table 9. Extent of use of computer in teaching the different subject areas of the elementary teachers of Southern Tabuk District-1 as to moderator of age

\begin{tabular}{|l|l|}
\hline Age & Mean \\
\hline $21-30$ years old & 2.08 \\
\hline $31-40$ years old & 2.14 \\
\hline 41 and above & 2.20 \\
\hline Total weighted mean & 2.14 \\
\hline
\end{tabular}

Chi-test $=6.346$, Chi-test $(.05)=9.49$, Ho accepted $/$ not significant.

career, it means that the acquire their competency in computer through informal training. This is supported by the study reported that there is no difference between the perceptions of urban and rural teachers and male and female teachers.

This is in contrast with the study of which states that there were significant differences in the perceptions of the elementary teachers of Eastern Tabuk District on the use of computer as to age.

Table 10 presents the extent of use of computer in teaching the different subject areas of elementary teachers of Southern Tabuk District-1 as to moderator variable of Gender.

Since the computed F-test of 0.01338 is lesser than the $F$-critical value of 0.0526 , the null hypothesis which states that there are no significant differences on the extent of use in teaching the different subject areas as to gender is accepted. Therefore, there are no significant differences on the extent of use in teaching the different subject areas as to gender.

Several studies have identified gender as a critical factor that affects teachers' attitude toward computer, but the findings did not affect the respondents' gender in the usage of computer though majority of the respondents were occupied by female but, there were no significant

Table 10. Extent of use of computer in teaching the different subject areas of elementary teachers of Southern Tabuk District-1 as to moderator variable of gender

\begin{tabular}{|l|l|}
\hline Gender & Mean \\
\hline Male & 2.05 \\
\hline Female & 2.23 \\
\hline Total weighted mean & 2.14 \\
\hline
\end{tabular}

$F$-test $=0.01338, F(.05)=0.0526$, Ho accepted $/$ not significant. relationship between gender and the elementary teachers of Southern Tabuk District-1 in the use of computer. This is also supported by his study in Gazi University, Turkey, which states that there were no significant differences between computer usage and gender variables.

Table 11 presents the extent use of computer in teaching the different subject areas of elementary teachers of Southern Tabuk District-1 as to moderator variable of years of service in teaching.

Since the computed F-test of 9.85 is lesser than the $F$-critical value of 9.49 , the null hypothesis which states that there are no significant differences on the extent of use in teaching the different subject areas as to years of service in teaching is rejected. Therefore, there are significant differences on the extent of use of computer to different subjects as to years of service in teaching.

As shown in the findings, it is expected that young teachers in the service tend to use computer than those who are older in the service. Older teacher in the service were unwillingly to use computer for their lesson that they are more comfortable to the traditional way of teaching, they believe that they can teach well even without computer. One reason is that they rely on their colleagues in terms of computer. In addition, their lack of knowledge is one factor by which they cannot integrate computer as they did not learn computer during their formative years of service. This is supported by the authors $\underline{24}$ that one of the major reasons for unsuccessful implementation of computers in teaching-learning process is the teacher's lack of knowledge/skills in use of computer. In the survey conducted by the authors, $\underline{25}$ on teachers of Uttarakhand, observed that teachers who are above 40 years of age and teachers with 20 years of experience and above showed a favorable opinion but used less in the classroom.

Table 11. Extent of use of computer in teaching the different subject areas of elementary teachers of Southern Tabuk District-1 as to moderator variable of years of service in teaching

\begin{tabular}{|l|l|}
\hline Years of service in teaching & Mean \\
\hline $1-10$ years of service in teaching & 2.24 \\
\hline $11-20$ years of service in teaching & 2.19 \\
\hline 21 and above years of service in teaching & 1.99 \\
\hline Total weighted mean & 2.14 \\
\hline
\end{tabular}

Chi-test $=9.85$, Chi-test $(.05)=9.49$, Ho rejected $/$ significant . 


\subsection{Problems Encountered by Elementary Teachers on the Use of Computer}

This section presents the respondents problems in dealing with computer in which they use numbers $1-7$ to specify or indicate their ranks to which is the most and least problems they encounter. Number 1 is the most problem and number 7 is the least.

Table 12 presents the problems encountered by elementary teachers of Southern Tabuk District-1 in using computer.

Table 12 presents the problems encountered by the respondents. It was ranked according to most to least. Inadequate training in computer is ranked as the most problem encountered, second is insufficient time to learn computer, third is too much work at home, fourth is dependence on colleagues, fifth is negative attitude towards computer, sixth is slow internet accessibility, and lastly has no computer to use.

\subsubsection{Inadequate Training in Computer}

The elementary teachers of Southern Tabuk District-1 rank inadequate training in Computer as first problem they encounter. As trainings have great impact on the part of the teachers, it is still claimed that the Division office have not yet conducted enough training for the elementary teachers of Southern Tabuk District-1. Seminars conducted regarding computer only requires 1-2 participants per school which the school heads send the ICT coordinator to go and relay it after. The ICT coordinator is then expected to conduct in-service training to her/his colleagues. But still these trainings are not more focused on basic computer skills, but more on forms to be submitted and expected the teachers already know how to accomplish it.

Table 12. Problems encountered by the elementary teachers of Southern Tabuk District-1 in using computer

\begin{tabular}{|l|l|}
\hline Problems & Ranks \\
\hline Inadequate trainings in computer & 1 \\
\hline Insufficient time to learn computer & 2 \\
\hline Dependence on colleagues & 4 \\
\hline Too much work at home and in school & 3 \\
\hline Negative attitude towards computer & 5 \\
\hline Slow internet accessibility & 6 \\
\hline Has no computer to use & 7 \\
\hline
\end{tabular}

Many studies had claimed that lack of training in computer covers all the factors that affect the competency of a teacher. Without training, teachers are unlikely to understand exactly how these feedback mechanisms work and therefore will not optimise their effectiveness. $\underline{26}$ In their study,, 27 among the 62 public elementary teachers of San Jose Elementary school, Division of Tacloban city, concluded that teachers have basic computer competency and it needs to be proficient in knowing where and when to use technology for teaching and other related tasks. It is then recommended that teachers undergo training that will help further enhance their computer skills and knowledge.

\subsubsection{Insufficient Time to Learn Computer}

Many of the respondent claimed that some trainings that were done are not enough for them to learn and master the skills, they need more time and support to be competent. It is often said that even if teachers attend seminar if not monitored and with no continuity of the skill it will not benefit the teachers. Teachers when given time to practice with technology, learn, share and collaborate with peer, it is likely that they will integrate the technology into their teaching. $\underline{28}$ Data collected from interviews conducted showed time as being most influential barrier to integrating new classroom strategies.

\subsubsection{Too much work at home}

Respondents identified it as one of the problems they encountered, they claimed that when they at home it is their time to be their family and other social responsibilities to attend.

\subsubsection{Dependence on Colleagues}

One of the problems faced by young teachers is dependence of other teachers especially the older ones. They rely most of their task when connected to computer to their colleagues. Even school heads assigned ICT coordinators, the mere fact that all documents nowadays require computer jobs will not guarantee that these will all accommodated by the coordinators.

\subsubsection{Negative Attitude Toward Computer}

The attitude has also an impact when regards to computer. If the teacher has negative attitude toward his/her use of computer most likely not use computer. Some elementary 
teachers of Southern Tabuk District-1 identified it as one of their barriers especially if there are new trends in using the Microsoft applications, their ability to adapt will be affected. Teacher must be encouraged to accept computer as part of the teaching-learning process. Positive attitude to computer is very important. Positive disposition towards computer is a prerequisite and catalyst to acquiring a high level of computer literacy and successful pedagogical use of Technology as cited. The teacher is a means to effective implementation of the use of computers in the educational system and teachers must have tremendous potential to transmit beliefs and attitudes to students, it is important to understand the factors that contribute to both positive and negative attitude of teachers to computer usage.

\subsubsection{Has No Computer to Use}

This is still one of the problems why teachers cannot use computer because they still have no personal computer to use. This collaborates with the study of analyzing the impact of owning computer were explored that this factor had a significant effect. It means that if a teacher has no computer to use, there is discontinuity of the skills she/ he learns or the law of misuse. The more the teacher is exposed to computer the more skills she/he will develop.

\section{Conclusion}

In the conducted study of the computer competency level of Elementary teachers in Southern Tabuk District-1, the perceptions of the respondents on the use of computer along Microsoft Applications is not significant. Therefore, for trainings, technical support, and time to learn these skills were needed by the respondents. On the extent to use computer in different subject areas, age and gender show no significant difference but years of service in teaching has a significant difference on the use of computer. This only implies that younger teachers in the service are more exposed and competent in the use of computer compare to those teacher 21 years above in the teaching.

Problems were also identified in the study; respondents specify each problem from most to least. Inadequate training is identified first, followed by insufficient time to learn computer, third is too much work at home, fourth is dependence on colleagues, fifth is negative attitude towards computer, sixth is slow internet accessibility, and lastly has no computer to use.

\section{Recommendations}

Based on the findings of the study, the following are recommended:

1. Depending on technological developments, teachers and administrators are needed to be updated and sustained.

2. Educational programs may be arranged flexibly in a way to obtain integration of computers in classrooms.

3. School heads may provide technical support and promote positive e-learning experience to every teacher regardless of their age and years of service in teaching.

4. Computer competency and attitude of teachers and the factors affecting them may be assessed at certain intervals

5. The Division of Tabuk City should pay more attention to the use of technologies existing at school personally and they should present teachers some facilitating applications.

\section{References}

1. Aduwa-Ogiegbaen SE. Nigerian inservice teachers' selfassessment in core technology competences and their professional development needs in ICT. J Comput Teach Educ. 2009;26(1):17-28.

2. Teachers' attitudes and levels of technology use in classrooms: the case of Jordan schools.[cited 2010 Apr]. https://www.researchgate.net/publication/43199030_ Teachers'Attitudes_and_Levels_of_Technology_Use_in_ Classrooms_The_Case_of_Jordan_Schools.

3. Computer- based writing instruction. [cited 2016]. https:// files.eric.ed.gov/fulltext/ED586512.pdf.

4. Developing information communication technology (ICT) curriculum standards for K-12 schools in the Philippines. Curriculum studies. [cited 2013]. https:// www.semanticscholar.org/paper/Developing-InformationCommunication-Technology-(-)-Bonifacio/7164ae5e942f 0bd45a8f1296677abd8714299d87.

5. Alternatives in implementation of e-course in chemistry and environmental protection, section "transition metals" $10^{\text {ms }}$ grade. [cited 2008 Jan]. https://www.researchgate.net/ publication/291480924_Alternatives_in_implementation_ ofe-course_in_chemistry_and_environmental_ protection_section_transition_metals_-10_grade.

6. An exploration of teachers' skills, perceptions and practices of ICT in teaching and learning in the Ghanaian second-cycle schools. [cited 2012]. https:// www.semanticscholar.org/paper/An-Exploration-of- 
Teachers\%E2\%80\%99-Skills\%2C-Perceptionsand-Buabeng-Andoh/ca 7 da 8 a a 6839 dd 2175 fcde df15d04b13504661d9.

7. An assessment of ICT competencies of publicschoolteachers: basis for community extension program. [cited 2017 Mar]. https://www.researchgate.net/publication/315436700_An_ Assessment_of_ICT_Competencies_of_Public_School_ Teachers_Basis_for_Community_Extension_Program.

8. Educational research: planning, conducting, and evaluating quantitative and qualitative research. [cited 2017]. http:// basu.nahad.ir/uploads/creswell.pdf.

9. Ertmer PA, Otterbreit-Leftwich A, Sadik O, Sendurur E, Sendurur P. Teacher beliefs and technology integration practices: a critical relationship. Comput Educ. 2012;59:123-435.

10. How to design and evaluate research in education. [cited 2011]. https://www.academia.edu/3642866/How_to_ Design_and_Evaluate_Research_in_Education.

11. Ghavifekr S, Rosdy WAW. Teaching and learning with technology: effectiveness of ICT integration in schools. Int J Res Educ Sci (IRES). 2015;1(2):175-91.

12. Hermans R, Tondeur J, Van Braak J, Valcke M. The impact of primary school teachers' educational beliefs on the classroom use of computers. Comput Educ. 2008;51:1499-509.

13. Multiple literacies and environmental science education: information communication technologies in formal and informal learning environments. [cited 2010]. https://www.igi-global.com/book/multiple-literacyscience-education/791.

14. Computer competency of incoming college students: yet more bad news. [cited 2008 Jan]. https://www.researchgate. net/publication/228889337_Computer_Competency_of_ Incoming_College_Students_Yet_More_Bad_News.

15. Hus V. The use of ICT in the environmental studies subject. In: 3rd world conference on educational sciences; 2011. vol. 15. P. 3855-60.

16. Johnson AM, Jacovina ME, Rusell DE, Sotto CM. Challenges and solutions when using technologies in the classroom. In: Adaptive educational technologies for literacy instruction; 2016. P. 13-29.

17. Kellenberger DW, Hendricks S. Predicting teachers' computer use for own needs, teaching and student learning. J Educ Comput Res. 2000;16(1):53-64.
18. Philippine digital literacy program to train and certify public school teachers. [cited 2008 Jul]. https://www.certiport. com/portal/common/documentlibrary/Lapus_070708.pdf.

19. Computer-assisted instruction in literacy skills for kindergarten students and perceptions of administrators and teachers. [cited 2017]. https://digital.library.unt.edu/ ark:/67531/metadc3651/.

20. Prioritization and implementation of information technology in higher education institutions in the Philippines. [cited 2017]. https://www.academia edu/29588176/Prioritization_and_Implementation_ of_Information_Technology_Funding_in_Higher_ Education_Institutions_in_the_Philippines.

21. Padmavathi M. A survey of secondary school teachers' perceptions, competency and use computers. Int J Educ Psychol Res (IJEPR). 2013;2(4):7-16.

22. Basic computer skills of primary school teachers and directors. [cited 2005]. https://www.academia edu/2597858/BASIC_COMPUTER_SKILLS_OF_ PRIMARY_SCHOOL_TEACHERS_AND_DIRECTORS.

23. Teck SH, Lai YL. An empirical analysis of Malaysian preuniversity students' ICT competency gender differences. Int J Netw Mob Technol. 2011;2:1-15.

24. Pre-service teachers' attitudes towards computer use: a Singapore survey. [cited 2008]. https://ajet.org.au/index. php/AJET/article/view/1201.

25. ICT competency standards for teachers. [cited 2008]. file://C:/Users/a/Downloads/competencias_tic_docentes_ marcos_politicas.pdf.

26. Uniyal NP, Pandey SK. Teachers' attitude towards computer in relation to sex, age, locality and experience. Exp Educ. 2008:1-6.

27. Social studies teachers' perspectives of technology integration. [cited 2007 Jan]. https://www.researchgate. net/publication/255566575_Social_Studies_Teachers'_ Perspectives_of_Technology_Integration.

28. Zorba E. Identifying the computer competency levels of recreation department of undergraduate. Turk Online J Educ Technol. 2011;10:10-14. 